\title{
Red dragon fruit (Hylocereus spp.) peel marmalade effectively improve blood glucose and lipid profile of hypercholesterolemic wistar rats
}

\author{
Natalia Desy Putriningtyas ${ }^{1 *}$, Intan Permatasari ${ }^{2}$, Dita Oktaviani $^{3}$, Anastasia Servia Raha ${ }^{4}$, Siti Wahyuningsih $^{5}$
}

\section{ABSTRACT}

Background: Polyphenols, antioxidants, dietary fiber, and vitamin contained in the red dragon fruit peel. Red dragon fruit peel can be processed into marmalade. Red dragon fruit peel marmalade has the potential to be a functional food. Functional food is food that has a physiological function based on scientific studies.

Objectives: The objective of this study is to analyze the effect of red dragon fruit peel marmalade on fasting blood glucose levels, $H D L, L D L$, and triglycerides levels of hypercholesterolemic Wistar rats.

Methods: This study used a pre-\&post-test control group design. Hypercholesterolemic male Wistar rats were randomly assigned into five groups. Hypercholesterolemia was induced by $1 \%$ cholesterol powder and $0.5 \%$ cholic acid for two weeks. All groups received standard chow. Samples were grouped into five groups: $\mathrm{K}-; \mathrm{K+} ; \mathrm{K} 1$ (0.94 g/kg b.wt/day); K2 (1.41 g/kg b.wt/day); K3 (1.88 g/kg b.wt/day). The intervention was carried out for 28 days. GDP level was measured using the GOD-PAP. $H D L, L D L$, and triglyceride were analyzed with spectrophotometry. GDP, HDL, LDL, and triglyceride levels were measured twice before fasting. A paired $t$-test and one-way ANOVA were used to analyze the data.

Results: The result showed that $K-; K 1 ; K 2 ; K 3$ had a significant difference between groups before and after the intervention ( $p<0.05)$. Red dragon fruit peel Marmalade was able to reduce the levels of GDP, LDL, triglycerides, and increase HDL ( $p$ $<0.05)$.

Conclusion: Red dragon fruit peel marmalade reduced fasting blood glucose levels, LDL, triglyceride levels, and increased HDL levels of hypercholesterolemic Wistar rats.

Keywords: blood glucose level; lipid profile; marmalade; pectin; red dragon fruit peel.

\section{INTRODUCTION}

Hypercholesterolemia is a primary health problem that is often associated with cardiovascular disease and fat abnormalities. Modern lifestyle, such as consumption of high-fat foods and lack of physical activity, is associated with the incidence of hypercholesterolemia and cardiovascular diseases. Moreover, increased levels of low-density lipoprotein (LDL) that accumulate in the subendothelial extracellular space in the arteries may trigger atherosclerosis, hypertension, obesity, diabetes, and even impair organ function (heart, liver, and kidney $)^{1}$. Clinical research showed that lowering cholesterol and LDL levels can reduce mortality and morbidity associated with complications of cardiovascular diseases and reduce progression caused by cardiovascular diseases ${ }^{2}$.

Oxidative stress triggers reactive oxygen species (ROS). The formation of several diseases, including atherosclerosis and coronary heart disease can be triggered by oxidative stress. Atherosclerosis in the vascular blood vessel walls can be formed by an increase in free radicals. Hence, hypercholesterolemia is associated with oxidative stress that results from increased production of ROS or a disturbance in the antioxidant system ${ }^{3}$.

Regular exercise, pharmacological therapy, and dietary habit are means of controlling blood glucose, LDL, high-density lipoprotein (HDL), and triglyceride levels. The recommended diet is to increase the intake of fiber and antioxidants from vegetables and fruits. Furthermore, the consumption of soluble fiber and antioxidants can reduce glucose levels and lipid profiles in the blood ${ }^{4}$. One of fruits that have high levels of soluble fiber and antioxidants is red dragon fruit.

The vitamins and minerals such as vitamins B1, B2, B3, C, protein, fat, carbohydrates, crude fiber, niacin, flavonoids, phenolics, betacyanins, polyphenols and phytoalbumin contained in red dragon fruit ${ }^{5}$. Dragon fruit peel contains phenolic compounds, flavonoids, anthocyanins, and triterpenoids ${ }^{6}$. However, the utilization of dragon fruit is only limited to the flesh, while dragon fruit peel is considered as waste ${ }^{7}$. The antioxidant activity of the red dragon fruit skin is higher

\footnotetext{
${ }^{1}$ Nutrition, Public Health Science Department, Faculty of Sport Science, Universitas Negeri Semarang. F5 Building UNNES Sekaran Gunungpati Semarang 50229, Central Java, Indonesia

${ }^{2}$ Dietisien Education, Nutrition Department, Poltekkes Kemenkes RI Yogyakarta. Tatabumi Number. 3 road, Banyuraden, Gamping, Sleman DIY 55293, Indonesia

${ }^{3}$ Family Pluit Hospital North Jakarta. Pluit Mas I/ 5A Road, Pejagalan, Penjaringan, North Jakarta, 14450 Indonesia

${ }^{4}$ Kalbu Intan Medika Hospital. Basuki Rahmat Road Number 888, Bukitintan, Bukit Intan, Pangkal Pinang City, Bangka Belitung 33141 Indonesia

${ }^{5}$ Nutrition Science, Faculty of Health Science, Universitas Respati Yogyakarta. Jl. Raya Tajem Km 1,5 Maguwoharjo Depok Sleman DIY, Indonesia

${ }^{*}$ Corresponding author : E-mail: nataliadesy@ mail.unnes.ac.id
} 
than the flesh, so it has the potential to be developed as a natural antioxidant ${ }^{8}$. The fiber content in the red dragon fruit flesh reaches $0.7-0.9 \mathrm{~g}$ per $100 \mathrm{~g}$. In the dragon fruit peel, it reaches $0.71 \mathrm{~g} / 100 \mathrm{~g}$. Pectin content in the red dragon fruit peel is $16.20-20.34 \%$ when extracted at a temperature of $80^{\circ} \mathrm{C}$ for $20-80$ minutes ${ }^{9}$. Pectin is a complex carbohydrate that can be used as a gelling agent, thickener, stabilizer, and emulsifier. Pectin is one of the ingredients needed in manufacturing ${ }^{10}$. Marmalade has a texture resembling jam with the addition of pieces of fruit skin ${ }^{11}$.

A study from Puspita shows that the administration of red dragon fruit peel brew for 14 days as much as $9.08 \mathrm{~g}$ per 200 grams of body weight could reduce LDL levels of Sprague Dawley rats with dyslipidemia by $43.33 \pm 3.65 \mathrm{mg} / \mathrm{dL}$. The reduction in LDL levels in the red dragon fruit peel brew was better when compared to the treatment of red dragon fruit juice as much as $1.53 \mathrm{~g}$ per 200 grams of body weight for 14 days in Sprague Dawley rats with dyslipidemia which could reduce LDL levels by $27.56 \pm 8.01 \mathrm{mg} / \mathrm{dL}$. The flavonoids content in dragon fruit peel can contribute as an antioxidant substance ${ }^{12}$. Research Faadlilah showed that the administration of red dragon fruit peel brew with a dose of $200 \mathrm{mg} / \mathrm{mL}, 400 \mathrm{mg} / \mathrm{mL}$ and $800 \mathrm{mg} / \mathrm{mL}$ for 14 days could increase serum HDL levels in Sprague Dawley rats with dyslipidemia ${ }^{13}$.

Processing of red dragon fruit peel is one of the innovations to utilize red dragon fruit waste. Red dragon fruit peel marmalade is produced with the addition of sucrose, which triggers the pectin to clot and forms fine fibers so that it is expected to create a gel properly ${ }^{14}$. Utilization of red dragon fruit peel into marmalade is expected to increase the economic value and selling power of red dragon fruit peel as well as the potential for dragon fruit peel as an alternative to functional food ingredients because of its antioxidant content. Marmalade is selected as one of the processed red dragon fruit peel. Red dragon fruit peel marmalade can maintain the presence of pectin and antioxidants so that the potential of dragon fruit peel as a functional food could be improved ${ }^{11}$. This study aims to determine the possibility of red dragon fruit skin marmalade on blood glucose, HDL, LDL, and triglyceride levels in hypercholesterolemic Wistar rats.

\section{MATERIAL AND METHODS}

\section{Process of Making Marmalade}

Red dragon fruit peel marmalade was made in the Laboratory of Dietetics and Culinary Universitas Respati Yogyakarta. The analyses of proximate, flavonoids, and cellulose contents were performed in the Laboratory of Chemistry, Center of Food and Nutrition Universitas Gajah Mada Yogyakarta. The marmalade has a texture resembling jam to which pieces of fruit peel were added.
The initial step of this marmalade making was sorting. The red dragon fruit peel was cleansed by flowing water; then a blender was used to make red dragon fruit peel puree. The puree was then cooked with additional fruit peel and sucrose. The ratio of the puree and the additional fruit peel was 3:1, and the concentration of added sucrose in this marmalade making process was $10 \%$ per 100 grams.

\section{Experimental Animals}

The study design was a true experiment involving pre-test, post-test, control group, and experimental group. The experiment was performed in the House of Experimental Rats CNFS Universitas Gajah Mada Yogyakarta that includes the purchasing and care of experimental animals, fasting blood glucose level test, HDL test, LDL test, and triglycerides test. The experiment was conducted in September 2018.

Research samples were male Wistar rats, aged 812 weeks, had an initial weight of 160-240 grams, had a normal fasting blood glucose level of $<110 \mathrm{mg} / \mathrm{dL}$, had no physical abnormalities and were healthy and active during the adaptation period. The rats were excluded if they were sick or inactive during the adaptation period, had an extreme weight loss (>10\%) before having study treatments, or having diarrhoea. Drop-outs were dead rats during the treatment period.

We prepared five treatment groups containing six Wistar rats each which made us used 30 rats in total (15). The room temperature for Wistar rats are $25 \pm 1^{\circ} \mathrm{C}, 12: 12$ hours of light/dark cycle, normal humidity. The sanitation and cleanliness were maintained to minimize stress during the experiment. Each rat was placed in a separated stainless-steel cage and was given standard cow with ad libitum water access. The adaptation period was done in seven days before treatments. Hypercholesterolemia was induced by feeding the rats with powder containing $1 \%$ cholesterol and $0.5 \%$ cholic acid for 14 days ${ }^{16}$. The feeding process was done using oral gavage. The cholesterol and cholic acid powder were obtained from Sigma Aldrich, Japan. Animal facilities, their management and handling during the experiment were done in compliance with the Guidelines for Care and Use of Laboratory Animals of CNFS Gajah Mada University. They were also approved by the Research Ethics Committee of the Universitas Respati Yogyakarta number 169.1/UNRIYO/PL/VII/2018.

\section{Experimental Design}

The Wistar rats were randomly assigned to five treatment groups after the hypercholesterolemia induction $(\mathrm{n}=6)$. K-: Control rats (not hypercholesterolemic and did not receive any treatment); $\mathrm{K}+$ : Hypercholesterolemic rats; $\mathrm{K}$ : Hypercholesterolemic rats that received the dragon fruit peel marmalade 0.94 grams per kg body weight per day via oral gavage for 28 fays; K2: Hypercholesterolemic rats that received the marmalade 1.41 grams per $\mathrm{kg}$ of 
body weight per day via oral gavage for 28 days; K3: Hypercholesterolemic rats that received the marmalade 1.88 grams per $\mathrm{kg}$ of body weight per day via oral gavage for 28 days. The intervention doses for $\mathrm{K} 1, \mathrm{~K} 2$, and $\mathrm{K} 3$ were derived from the daily dose of sucrose consumption. A balanced diet recommends a maximum of 4 tbsp of sucrose consumption per day ${ }^{17}$. The marmalade was given every morning. During the study, one experimental animal in $\mathrm{K}$ - died due to getting bitten by another rat next to the cage. The final number of experimental animals was 29 . The bodyweight of the rats was weighed using an electric scale with an accuracy of 0.01 grams.

\section{Collection of Samples}

Measurements of fasting blood sugar level, HDL, LDL and triglycerides levels were carried out after the induction of hypercholesterolemia, before and after treatments for each group. The measurements used blood serum obtained from the retroorbital plexus in the eye after the rats had fasted for 6 hours. The fasting blood sugar level was analyzed using the GOD-PAP (Glucose Oxidase Phenol 4- Aminophenazone) method, while the measurements of HDL, LDL and triglyceride levels using the spectrophotometric method.

\section{Statistical Analysis}

Pre-test and post-test treatments was measured. The mean \pm standard deviation were reported. As all data were normally distributed, the significance of differences before and after treatments was determined between using the paired t-test. The significance of differences between the groups was determined using one-way analysis of variance (ANOVA), with a significance level of $\mathrm{p}<0.05$ by the LSD Test.

Table 1. The Nutrition of Marmalade

\begin{tabular}{lllllll}
\hline Ingredient & Water (\%) & Fat (\%) & Protein (\%) & Carbohydrate (\%) & Cellulosa (\%) & Flavonoid (\%) \\
\hline $\begin{array}{l}\text { Red dragon fruit } \\
\text { peel marmalade }\end{array}$ & 80.49 & 0.08 & 0.62 & 17.75 & 3.31 & 0.02 \\
\hline
\end{tabular}

Table 2. The Parameters of Experimental Rats During The Study

\begin{tabular}{|c|c|c|c|c|c|}
\hline $\begin{array}{l}\text { Parameters } \\
\text { tested }\end{array}$ & $\begin{array}{l}\text { K-a } \\
\text { mean } \pm S D\end{array}$ & $\begin{array}{l}\mathrm{K}+^{\mathrm{b}} \\
\text { mean} \pm \mathrm{SD}\end{array}$ & $\begin{array}{l}\mathrm{K1}^{\mathrm{c}} \\
\text { mean } \pm \mathrm{SD}\end{array}$ & $\begin{array}{l}\mathrm{K}^{\mathrm{d}} \\
\text { mean } \pm \mathrm{SD}\end{array}$ & $\begin{array}{l}\mathrm{K3}^{\mathrm{e}} \\
\text { mean } \pm \mathrm{SD}\end{array}$ \\
\hline \multicolumn{6}{|l|}{ Body weight } \\
\hline pre & $73.79 \pm 5.53$ & $155.16 \pm 9.61$ & $159.50 \pm 2.90$ & $152.18 \pm 4.01$ & $154.47 \pm 3.53$ \\
\hline post & $74.22 \pm 5.33$ & $158.44 \pm 6.73$ & $140.86 \pm 1.85$ & $114.68 \pm 3.42$ & $91.28 \pm 2.47$ \\
\hline$\Delta$ & $0.43 \pm 0.36^{\mathrm{b}, \mathrm{c}, \mathrm{d}, \mathrm{e}}$ & $3.28 \pm 3.17^{\mathrm{a}, \mathrm{c}, \mathrm{d}, \mathrm{e}}$ & $-18.65 \pm 1.99^{a, b}$ & $-37.50 \pm 0.66^{a, b, e}$ & $-63.20 \pm 1.50^{\mathrm{a}, \mathrm{b}, \mathrm{d}}$ \\
\hline $\mathrm{p}^{*}$ & $0.033 *$ & 0.082 & $0.001 *$ & $0.001 *$ & $0.001 *$ \\
\hline \multicolumn{6}{|l|}{ Glucose } \\
\hline pre & $73.79 \pm 5.53$ & $155.16 \pm 9.61$ & $159.50 \pm 2.90$ & $152.18 \pm 4.01$ & $154.47 \pm 3.53$ \\
\hline post & $74.22 \pm 5.33$ & $158.44 \pm 6.73$ & $140.86 \pm 1.85$ & $114.68 \pm 3.42$ & $91.28 \pm 2.47$ \\
\hline$\Delta$ & $0.43 \pm 0.36^{\mathrm{b}, \mathrm{c}, \mathrm{d}, \mathrm{e}}$ & $3.28 \pm 3.17^{\mathrm{a}, \mathrm{c}, \mathrm{d}, \mathrm{e}}$ & $-18.65 \pm 1.99^{\mathrm{a}, \mathrm{b}, \mathrm{d}, \mathrm{e}}$ & $-37.50 \pm 0.66^{\mathrm{a}, \mathrm{b}, \mathrm{c}, \mathrm{e}}$ & $-63.20 \pm 1.50^{\mathrm{a}, \mathrm{b}, \mathrm{c}, \mathrm{d}}$ \\
\hline $\mathrm{p}^{*}$ & $0.033^{*}$ & 0.082 & $0.001 *$ & $0.001 *$ & $0.001 *$ \\
\hline \multicolumn{6}{|l|}{ HDL-C } \\
\hline pre & $78.68 \pm 2.26$ & $25.30 \pm 1.21$ & $23.92 \pm 1.17$ & $26,07 \pm 1,46$ & $26.30 \pm 2.93$ \\
\hline post & $78,06 \pm 2.25$ & $23.08 \pm 1.21$ & $43.62 \pm 2.00$ & $61,03 \pm 2,32$ & $67.15 \pm 4.09$ \\
\hline$\Delta$ & $-0.62 \pm 0.01^{\mathrm{c}, \mathrm{d}, \mathrm{e}}$ & $-2.22 \pm 0^{\mathrm{c}, \mathrm{d}, \mathrm{e}}$ & $19.7 \pm 0.83^{\mathrm{a}, \mathrm{b}, \mathrm{d}}$ & $34,96 \pm 0.86^{\mathrm{a}, \mathrm{b}, \mathrm{c}, \mathrm{e}}$ & $40.85 \pm 1.16^{\mathrm{a}, \mathrm{b}, \mathrm{c}, \mathrm{d}}$ \\
\hline $\mathrm{p}^{*}$ & $0.007 *$ & $0.045^{*}$ & $0.001 *$ & $0,001 *$ & $0.001 *$ \\
\hline \multicolumn{6}{|l|}{$L D L-C$} \\
\hline Pre & $27.91 \pm 1.49$ & $76.40 \pm 1.80$ & $77.39 \pm 1.87$ & $75,43 \pm 2,00$ & $82.58 \pm 6.02$ \\
\hline Post & $29.41 \pm 1.29$ & $77.09 \pm 1.66$ & $52.82 \pm 2.79$ & $44,86 \pm 2,88$ & $33.91 \pm 1.80$ \\
\hline$\Delta$ & $1.5 \pm 0.20^{\mathrm{c}, \mathrm{d}, \mathrm{e}}$ & $0.69 \pm 0.14^{\mathrm{c}, \mathrm{d}, \mathrm{e}}$ & $24.57 \pm 0.92^{\mathrm{a}, \mathrm{b}, \mathrm{d}, \mathrm{e}}$ & $30,57 \pm 0.88^{\mathrm{a}, \mathrm{b}, \mathrm{c}, \mathrm{e}}$ & $48.67 \pm 4.22^{\mathrm{a}, \mathrm{b}, \mathrm{c}, \mathrm{d}}$ \\
\hline $\mathrm{p}^{*}$ & $0.001 *$ & 0.519 & $0.001 *$ & $0,001 *$ & $0.001 *$ \\
\hline \multicolumn{6}{|l|}{ Triglyceride } \\
\hline Pre & $67.72 \pm 2.04$ & $142.29 \pm 2.43$ & $144.13 \pm 3.30$ & $141.37 \pm 3.44$ & $141.37 \pm 3.44$ \\
\hline Post & $69.03 \pm 2.77$ & $141.37 \pm 3.44$ & $111.98 \pm 7.10$ & $87.14 \pm 3.30$ & $79.90 \pm 4.77$ \\
\hline$\Delta$ & $1.31 \pm 0.73^{\mathrm{c}, \mathrm{d}, \mathrm{e}}$ & $-0.42 \pm 1.01^{\mathrm{c}, \mathrm{d}, \mathrm{e}}$ & $-32.24 \pm 3.8^{\mathrm{a}, \mathrm{b}, \mathrm{d}, \mathrm{e}}$ & $-54.23 \pm 0.14^{\mathrm{a}, \mathrm{b}, \mathrm{c}, \mathrm{e}}$ & $-67.53 \pm 1.33^{\mathrm{a}, \mathrm{b}, \mathrm{c}, \mathrm{d}}$ \\
\hline $\mathrm{p}$ & $0.020^{*}$ & 0.900 & $0.001^{*}$ & $0.001^{*}$ & $0.001^{*}$ \\
\hline \multicolumn{6}{|c|}{ 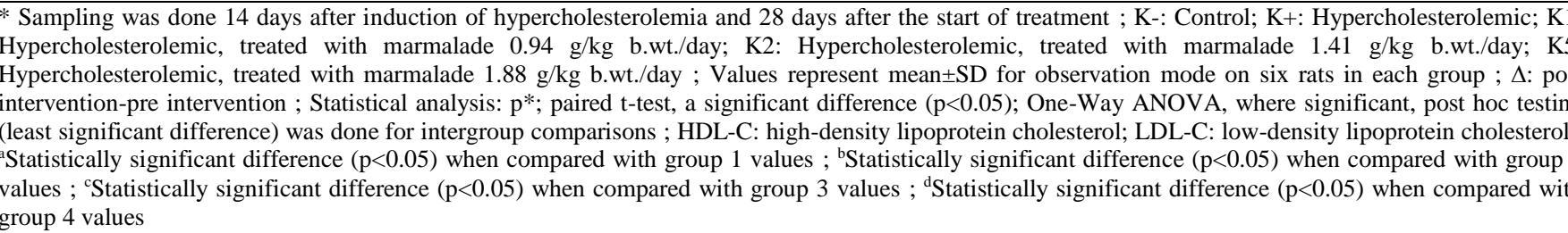 } \\
\hline
\end{tabular}




\section{RESULTS}

The body weighing process aims to observe the rats' growth during the study. The average body weight of rats in each group can be seen in Table 2. Statistical results from the paired t-test showed significant differences in each group before treatments $(\mathrm{p}<0.05)$. The positive control group had the highest body weight changes, while the negative control had the lowest.

Group K3 had the lowest weight gain and the highest blood sugar level reduction compared to all groups. Blood glucose level is one of the parameters for insulin resistance. Further analyses using ANOVA showed that the administration of the dragon fruit peel marmalade in various doses could reduce body weight and blood glucose levels in each group.

The HDL levels also increased in all groups receiving the marmalade. The highest increase was observed in Group K3. The difference of HDL levels between before and after treatments in the five experimental groups showed a significant difference $(p<0.05)$. Further analyses using ANOVA showed a difference in each group. The LDL levels in Group K+ did not show a significant difference between before and after treatments ( $p>0.05$ ). The LDL levels in $\mathrm{K} 1, \mathrm{~K} 2$, and K3 decreased after the intervention. Group K3, which had given the marmalade of 1.88 grams, had a decrease until $48.67 \pm 4.22 \mathrm{mg} / \mathrm{dL}$. The result from ANOVA showed a significant difference between the groups $(\mathrm{p}<0.05) . \mathrm{K} 3 \mathrm{had}$ a decrease of triglycerides levels until $67.53 \pm 1.33 \mathrm{mg} / \mathrm{dL}$. The ANOVA results showed no significant difference between positive control and negative control $(p>0.05)$ but showed a significant difference between the treatment groups $(\mathrm{p}<0.05)$.

\section{DISCUSSION}

Dietary fiber is found in red dragon fruit peel as much $3.31 \%^{18}$. The insoluble fiber of cellulose provides satiety which reduces calories intake and helps weight loss. Another fiber contained in the red dragon peel is pectin. It is soluble fiber which can hold water and form fluids in the digestive tract so the stomach will digest food longer. Moreover, it will also attract water and provide satiety longer, thus preventing more food consumption ${ }^{4}$.

High fiber diet has an excellent effect on glycemic control $^{4}$. The carbohydrate metabolism related to fiber. The type of fiber can affect physiological and metabolic effects. Soluble fiber can absorb fluids and form a gel in the stomach. The gel will slow down gastric emptying and nutrient absorption, including glucose ${ }^{19}$. The phenolic, flavonoid, and anthocyanin in red dragon fruit peel may reduce glucose level. Phenolic is a substituted phenol in various tropical plants. Research conducted by Suci shows that the red dragon fruit filtrate reduces blood glucose levels of glucose-induced mice. The content of flavonoids also lowers blood glucose levels by increasing the permeability of the pancreatic $\beta$ cell membrane so that insulin can be secreted ${ }^{20}$.

Red dragon fruit peel contains a high amount of fiber (69.3\%): $14.82 \%$ of soluble fiber and $56.50 \%$ of insoluble fiber ${ }^{21}$. Fiber can reduce LDL cholesterol levels by several mechanisms. It lowers cholesterol absorption and bile acid reabsorption in the intestinal lumen. A large quantity of bile acids excretion causes a decrease in the enterohepatic bile acids circulations followed by an increase of the conversion of cholesterol to bile acids in the liver and an increase of cholesterol circulation from the bloodstream to the liver ${ }^{22}$. The fermentation of soluble fiber in the colon will increase the expression of the gut-derived proglucagon gene and secretion of proglucagon-derived peptides. Proglucagonderived peptides belong to the glucagon-like peptide 1 (GLP-1) and peptide YY (PYY) groups. GLP-1 plays a role in inducing satiety by reducing the rate of gastric emptying, triggering glucose uptake from blood and storing glucose in peripheral tissues and inhibiting glucagon secretion. A lipolysis and beta-oxidation can be triggered via glucagon secretion. The cholesterol formation can be triggered by lipolysis and betaoxidation. A fatty acids and Acetyl-CoA which are formed during the process of lipolysis and beta-oxidation contribute to an increase in cholesterol levels ${ }^{23}$.

Marmalade used in this study is jellified marmalade. It is marmalade with the addition of sugar in its manufacturing process. This study used granulated sugar (sucrose) which was added to enhance the flavor as well as to preserve the marmalade. Food with high sugar content has a longer shelf life compared to food with low sugar content ${ }^{24}$. Research conducted by Olga found that rosella flower marmalade with a sugar concentration of $10 \%$ has a moisture content of $46.2 \%$ and can last up to 7 weeks ${ }^{25}$. Indonesian National Standard (SNI) for marmalade states that the minimum amount of dissolved solids in marmalade product is $65 \%$ ${ }^{26}$ and there are four critical substances needed in the process of making fruit gels, namely pectin, acid, sugar and water ${ }^{11}$. The marmalade of red dragon fruit peel in this study has an $80.49 \%$ water content. This high watercontent will support the bacteria to grow, which affect the shelf life ${ }^{11}$. The addition of sucrose to food products can affect their levels of antioxidants. Research conducted by Larasati showed the higher the sucrose content of a product, the lower its antioxidant activity ${ }^{27}$.

Determination of the doses used in this study was based on sugar consumption requirement for human, which is 4 tbsp per day with a weight assumption of $13 \mathrm{~g}$ per tbsp. The doses given in this study when converted into a dose for humans are $52.64 \mathrm{~g}$ ( 4 tbsp/day) for a dose of $0.94 \mathrm{~g} ; 78.96 \mathrm{~g}$ ( 6 tbsp/day) for $1.41 \mathrm{~g}$ and $105.28 \mathrm{~g}$ (8 tbsp/day) for $1.88 \mathrm{~g}$. Marmalade is commonly consumed 
as a spread of bread at breakfast or during a snack. The amount of marmalade applied is around 1-2 tablespoons/consumption. If converted according to the recommended dosage, it takes two times the consumption of marmalade per day to meet the dosage in this study.

The HDL levels in this study increased up to 40.85 $\pm 1.16 \mathrm{mg} / \mathrm{dL}$. These are in line with Faadilah's study which found that the most significant increase in HDL levels was on the treatment group with a dose of 800 $\mathrm{mg} / \mathrm{dl}^{13}$. The mechanism of reducing HDL levels by red dragon fruit peel marmalade might be due to its antioxidant property (flavonoids). The lecithincholesterol acyltransferase (LCAT) activity can be increased by flavonoids. The LCAT is an enzyme that converts free cholesterol into ester cholesterol. The LCAT can bind ester cholesterol to lipoprotein core particles and form HDL. The HDL levels can be increased by the content of palmitic acid and flavonoids in dragon fruit flesh and peel ${ }^{28,29}$.

The highest decrease in LDL levels was in the K3 group (with a dose of 1.88 grams), and the lowest decrease in LDL levels was in the K1 group (with a dose of 0.94 grams). This shows that the reduction is proportional to the dose given. This study indicates that the red dragon fruit peel marmalade with various doses can reduce LDL levels. Brewing dragon fruit peel as much of $9.08 \mathrm{~g} / 200 \mathrm{Gbb}$ of Sprague Dawley for 14 days could reduce the highest LDL levels up to $43.33 \pm 3.65$ $\mathrm{mg} / \mathrm{dl}^{12}$. Research by Werdiningsih showed that the red dragon fruit peel extract could reduce LDL levels, with the most significant dose of 1.44 grams $^{30}$. Red dragon fruit peel marmalade contains flavonoids, betacyanin, anthocyanin, pectin and dietary fiber. Antioxidants, such as flavonoids, betacyanin and anthocyanins, and the fiber content in red dragon fruit peel marmalade can reduce LDL levels. Flavonoids are cholesterol esterase coenzyme cofactors. They can scavenge and neutralize free radicals such as reactive oxygen species (ROS) or reactive nitrogen species (RNS), which bond to phenolic $\mathrm{OH}$ groups, and repair damaged tissue or inhibit the inflammatory process ${ }^{31,32}$. The myeloperoxidase/LDL oxidation induced by nitrate through scavenging activity (deactivation) of lipoperoxyl radicals can be inhibited by betacyanin in red dragon fruit peel. Anthocyanins in dragon fruit peel are considered to have the ability to inhibit CETP activity which prevents the exchange of cholesterol and triglycerides between HDL and LDL. The cholesterol-7a hydroxylase enzyme can be increased by vitamin $\mathrm{C}$ in red dragon fruit peel. The cholesterol-7a hydroxylase enzyme can converts cholesterol into bile acids and bile salts in the liver which are later excreted into the intestine and excreted through feces ${ }^{33}$. A catechin, epicatechin, routine, quercetin, myricetin and kaempferol are types of flavonoids in red dragon fruit peel. The highest concentration of flavonoids in red dragon fruit peel is cathecins. Activation of peroxisome proliferator activated receptor (PPAR) by increasing the level of mRNA expression genes from various adipogenic markers, such as adinopectin, PPAR- $\gamma$, FABP4 and LPL is influenced by cathecins ${ }^{34}$.

The results of this study indicated that the administration of red dragon fruit peel marmalade can lower triglyceride levels with the most significant decrease is in the administration of $1.88 \mathrm{~g} / \mathrm{kg} \mathrm{b}$.wt/day for 28 days. These results are in line with other studies which show that administration of red dragon fruit peel extract can reduce triglyceride levels in Sprague Dawley rats. This decrease in triglycerides levels might be due to the presence of catechin flavonoids, ascorbic acid, betacyanin, and soluble and insoluble fiber in the red dragon fruit peel extract ${ }^{35}$.

The antioxidant property of red dragon fruit peel contributes to the decreasing of triglyceride levels in dyslipidemic rats in this study. Red dragon fruit peel contains flavonoids catechins, ascorbic acid, betacyanin, and soluble and insoluble fiber. The flavonoid is in the form of catechin polyphenol active compounds, i.e.epigallocatechin-3 gallate (EGCG), epigallocatechin (EGC), epicatechin-3-gallate (ECG) and epicatechin (EC). Moreover, PPAR- $\alpha$ flavonoids can improve lipid profiles. It increases PPAR- which will reduce the expression of sterol regulatory element-binding protein 1c (SREBP-1c) in rat liver to reduce triglyceride synthesis, denovo free fatty acid formation and acetylCoA carboxylase activity (ACC) in mouse hepatocytes ${ }^{36}$. The triglyceride levels in male dyslipidemia rats can be reduced up to $25.3 \%$ by administering the infusion of red dragon fruit peel (Hylocereus polyrhizus). The reduced triglyceride levels is due to the presence of flavonoids in the infusion of red dragon fruit peel (Hylocereus polyrhizus $)^{37}$. Anthocyanin polyphenols in red dragon fruit peel scavenge free radicals and prevent lipid peroxidation processes in the microsomes and liposomes. Furthermore, it will reduce the secretion of lipoproteins in the liver and intestines. The anthocyanins help reduce cholesterol levels by inhibiting cholesterol formation and activate AMP-Activated Protein Kinase (AMPK). This AMPK involves in the homeostatic regulation of energy and influences the activity of many enzymes. One of the enzymes inhibited by AMPK is HMG-CoA reductase which involves in cholesterol cause an increase in fatty acid oxidation and a decrease in fatty acid synthesis, and lead to reduction in triglycerides levels ${ }^{37}$. Betacyanin pigment is a derivative of beta-alanine which well known for its benefits as an anti-radical and anti-oxidative compound.

Soluble fiber (pectin) and the insoluble fiber content of red dragon fruit peel can reduce triglyceride levels in dyslipidemic rats. They delay gastric emptying, so satiety lasts longer, resulting in reduced calorie intake $^{35}$. An acetate, propionate and butyrate are short- 
chain fatty acids that are produced in the intestines as a result of fermentation from fiber. Cholesterol and triglycerides synthesis can be reduced by propionate through inhibition of the HMG-CoA reductase enzyme. This process occurs in the liver ${ }^{38}$. The triglyceride levels in white male rats fed a high-fat diet can be reduced due to the fiber content in red dragon fruit peel ${ }^{30}$. The results of this study indicated that the average reduction in triglyceride levels in the administration of red dragon fruit peel marmalade with hypercholesterolemic rats is (22.4\%) for marmalade at a dose of $0.94 \mathrm{~g} / \mathrm{kg} \mathrm{b} . w \mathrm{t} /$ day, (37.6\%) for marmalade at a dose of $1.41 \mathrm{~g} . / \mathrm{kg} \mathrm{b} . w \mathrm{t} /$ day and $(45.8 \%)$ for marmalade, the dose is $1.88 \mathrm{~g} / \mathrm{kg}$ b.wt/day.

\section{CONCLUSION}

Administration of red dragon fruit peel marmalade at the dose of $0.94 \mathrm{~g} / \mathrm{kg} \mathrm{b} . \mathrm{wt} /$ day, $1.41 \mathrm{~g} / \mathrm{kg} \mathrm{wt} /$ day and $1.88 \mathrm{~g} / \mathrm{kg} \mathrm{b}$.wt/day could reduce levels of blood glucose, LDL, triglycerides and increase HDL levels of hypercholesterolemic Wistar rats. Administration of red dragon fruit peel marmalade with a dose of $1.88 \mathrm{~g} / \mathrm{kg}$ b.wt/day showed better results for improving fasting blood glucose, HDL, LDL and triglyceride levels hypercholesterolemic Wistar rats compared to the dose of $0.94 \mathrm{~g} / \mathrm{kg} \mathrm{b} . w \mathrm{t} / \mathrm{day}$ and $1.41 \mathrm{~g} / \mathrm{kg}$ b.wt $/$ day.

\section{ACKNOWLEDGEMENT}

Supported by research project LLDIKTI Region V Yogyakarta year 2018.

\section{REFERENCES}

1. Venkadeswaran K, Muralidharan A, Annadurai T, Ruban V, Sundararajan M, Anandhi R, et al. Antihypercholesterolemic and antioxidative potential of an extract of the plant, piper betle, and its active constituent, eugenol, in Triton WR-1339Antihypercholesterolemic and antioxidative potential of an extract of the plant, piper betle, and I. Evid Based Complement Altern Med. 2014;2014:1-10.

2. Song H, Chu Q, Yan F, Yang Y, Han W, Zheng X. Red pitaya betacyanins protects from diet- induced obesity, liver steatosis and insulin resistance in association with modulation of gut microbiota in mice. J Gastroenterol Hepatol. 2016;31(8):1462-9.

3. Bloomer RJ, Trepanowski JF, Kabir MM, Jr RJA, Dessoulavy ME. Impact of short-term dietary modification on postprandial oxidative stress. Nutr J. 2012;11(16):1-9.

4. Maćkowiak K, Torlińska-Walkowiak N, Torlińska B. Dietary fibre as an important constituent of the diet. Postep Hig Med Dosw. 2016;70:104-9.
5. Choo WS, Yong WK. Antioxidant properties of two species of Hylocereus fruits. Advances in Applied Science Research. 2011;2(3):418-25.

6. Laxmi SN, Tjandrakirana, Kuswanti N. Pengaruh filtrat kulit buah naga merah (Hylocereus polyrhizus) terhadap kadar glukosa darah mencit (Mus musculus) yang diinduksi glukosa. Lentera Bio. 2017;6(1):1-5.

7. Wahyuni R. Pemanfaatan kulit buah naga super merah (Hylocereus costaricensis) sebagai sumber antioksidan dan pewarna alami pada pembuatan jelly. Jurnal Teknologi Pangan. 2011;2(1):69-85.

8. Nurliyana R, Zahir S, Suleiman M, Aisyah M, Rahim K. Antioxidant study of pulps and peels of dragon fruits: a comparative study. IFRJ. 2010;17:367-75.

9. Zaidel DNA, Rashid JM, Hamidon NH, Salleh LM, Kassim ASM. Extraction and characterisation of pectin from dragon fruit (hylocereus polyrhizus) peels. Chemical Engineering Transactions. 2017;56:805-10.

10. Wolf B. Confectionery and sugar-based Foods [Internet]. Reference Module in Food Science. Elsevier; 2016. 1-4 p.

11. Smith DA. Jams and preserves/ Methods of manufacture. Encycl Food Sci Nutr. 2003;3409-15.

12. Puspita R, Ardiaria M, Syauqy A. Perbedaan efek seduhan kulit dan jus buah naga merah (Hylocereus polyrhizus) terhadap kadar kolesterol LDL serum tikus Sprague dawley dislipidemia. Jurnal Kedokteran Diponegoro. 2016;5(4):1559-67.

13. Faadlilah N, Ardiaria M. Efek pemberian seduhan kulit buah naga merah (Hylocereus polyrhizus) terhadap kadar HDL tikus Sprague dawley dislipidemia. Journal of Nutrition College. 2016;5(4):280-8.

14. Farikha IN, Anam C, Widowati E. Pengaruh jenis dan konsentrasi bahan penstabil alami terhadap karakteristik fisikokimia sari buah naga merah (Hylocereus polyrhizus ) selama penyimpanan. Jurnal Teknosains Pangan. 2013;2(1):30-8.

15. Charan J, Kantharia N. How to calculate sample size in animal studies? J Pharmacol Pharmacother. 2013;4(4):303-6.

16. Murase T, Yamada N, Uchimura H. Accumulation of intermediate density lipoprotein in the plasma of cholesterol-fed hypothyroid rats. Metabolism. 1983;32(2):146-50.

17. Menteri Kesehatan RI. Peraturan Menteri Kesehatan Republik Indonesia Nomor 30 Tahun 2013 tentang Pencantuman Informasi Kandungan Gula, Garam, dan Lemak serta Pesan Kesehatan untuk Pangan Olahan dan Pangan Siap Saji. Jakarta; 2013.

18. Hadi NA, Mohamad M, Rohin MAK, Yusof RM. Effects Of red pitaya fruit (Hylocereus Polyrhizus) 
consumtion on blood glucose level and lipid profile in type 2 diabetic subjects. Borneo Science [Internet]. 2012;(31):113-29.

19. Panjuantiningrum F. Pengaruh pemberian buah naga merah (Hylocereus polyrhizus) terhadap kadar glukosa darah tikus putih yang diinduksi aloksan. Surakarta: Universitas Sebelas Maret; 2009.

20. Saji N, Francis N, Schwarz LJ, Blanchard CL, Santhakumar AB. Rice bran derived bioactive compounds modulate risk factors of cardiovascular disease and type 2 diabetes mellitus: An updated review. Vol. 11, Nutrients. MDPI AG; 2019.

21. Jaya IKD. Morphology and physiology of pitaya and it future prospects in Indonesia. Crop Agro. 2010;3(1):44-50.

22. Asgary S, Rastqar A, Keshvari M. Functional food and cardiovascular disease prevention and treatment: A Review. J Am Coll Nutr [Internet]. 2018;37(5):429-55.

23. Tvrzicka E, Kremmyda LS, Stankova B, Zak A. Fatty acids as biocompounds: Their role in human metabolism, health and disease - a review. part 1: Classification, dietary sources and biological functions. Biomed Pap Med Fac Univ Palacky Olomouc Czech Repub. 2011;155(2):117-30.

24. Yadav AK, Singh SV. Osmotic dehydration of fruits and vegetables: a review. J Food Sci Technol. 2014;51(9):1654-73.

25. Paruntu OL, Ranti IN. Analisis kandungan vitamin $\mathrm{C}$, mutu organoleptik, mutu fisik dan kimia marmalade bunga rosella merah (Hibiscus sabdariffa, Linn) pada konsentrasi gula bervariasi. Gizido. 2015;7(2):404-7.

26. Badan Standarisasi Nasional. SNI Marmalade (SNI 01-4467-1998). Jakarta: Badan Standarisasi Nasional- BSN; 1998. 1-5 p.

27. Larasati I. Aktivitas antioksidan sirup kombinasi ekstrak kulit manggis dan daun sirsak dengan penambahan variasi konsentrasi gula pasir. Surakarta: Universitas Muhammadiyah Surakarta; 2015.

28. Kamanna VS, Kashyap ML. Mechanism of action of niacin. Am J Cardiol. 2008;101(8 SUPPL. 1).

29. Kamanna VS, Ganji SH, Kashyap ML. Recent advances in niacin and lipid metabolism. Curr Opin
Lipidol. 2013;24(3):239-45.

30. Werdiningsih $\mathrm{W}$. Efek pemberian kulit buah naga merah (Hylocereus polyrhizus) terhadap perubahan profil lipid tikus putih (Rattus norvegicus) jantan yang diberi diet tinggi lemak. Surabaya: Universitas Airlangga; 2017.

31. Zainoldin K hazmi, Baba AS. The Effect of Hylocereus polyrhizus and Hylocereus undatus on physicochemical, proteolysis, and antioxidant activity in yogurt. World Academy Science, Engineering and Technology. 2009;(60):361-6.

32. Estruch R, Martínez-González MA, Corella D, Basora-Gallisá J, Ruiz-Gutiérrez V, Covas MI, et al. Effects of dietary fibre intake on risk factors for cardiovascular disease in subjects at high risk. J Epidemiol Community Health. 2009;63(7):582-8.

33. Ayala A, Muñoz MF, Arguelles S. Lipid Peroxidation: production, metabolism, and signaling mechanism of malondialdehyde and 4Hydroxy-2-Nonenal. Oxidative Medicine and Cellular Longevity. 2014;98:1-32.

34. Grygiel-Górniak B. Peroxisome proliferatoractivated receptors and their ligands: Nutritional and clinical implications - A review. Nutr J. 2014;13(17):1-10.

35. Pramana IDGA, Ardiaria M, Syauqy A. Perbedaan efek seduhan kulit dan jus buah naga merah (Hylocereus polyrhizus) terhadap kadar trigliserida serum tikus Sprague Dawley dislipidemia. Jurnal Kedokteran Diponegoro [Internet]. 2016;5(4):9941006.

36. Wakil SJ, Abu-Elheiga LA. Fatty acid metabolism: Target for metabolic syndrome. J Lipid Res. 2009;50 (Suppl): S138-43.

37. Meidayanti Putri N, Gunawan IWG, Suarsa IW. Aktivitas antioksidan antosianin dalam ekstrak etanol kulit buah naga super merah (Hylocereus costaricensis) dan analisis kadar totalnya. Jurnal Kimia. 2015;9(2):243-51.

38. Yuliana AR. Efek pemberian seduhan kulit buah naga merah ( Hylocereus polyrhizus ) terhadap kadar trigliserida tikus Sprague dawley dislipidemia. Semarang: Universitas Diponegoro; 2016. 